\title{
Penerapan Mesin Pengasapan Ikan untuk Nelayan Desa Langkak Kecamatan Kuala Pesisir Kabupaten Nagan Raya
}

\author{
Muzakir1, Fitriadi1 ${ }^{1,}$, Iing Pamungkas ${ }^{1}$, Khairul Hadi', Heri Tri Irawan1, Arie \\ Saputra', Rita Hartati ${ }^{1}$
}

1Jurusan Teknik Industri, Fakultas Teknik, Universitas Teuku Umar

Email: fitriadi@utu.ac.id

Submitted: 29-06-2020 Revised: 20-07-2020 Accepted: 24-07-2020

\begin{abstract}
Fish is one of the species that is in high demand by consumers, including in Aceh. Fish can be obtained by catching from abundant nature. Problems in processing fish catches in Aceh, especially Langkak Village, Kuala Pesisir District, Nagan Raya Regency is a conventional post-capture processing method, which is drying using the heat of sunlight. In this condition, fish drying has several disadvantages, which are related to dependence on sunlight heat, cleanliness, freshness of fish, and selling points. For this reason, there needs to be a way to implement simple technology that uses a fish fogging machine. The purpose of carrying out this community service program is to provide practical applications of the fish fogging technique by providing soft skills to members of the fishing group in the Village of Langkak Village, Kuala Pesisir District, Nagan Raya Regency. The results of community service activities have been going well, starting with socialization activities or theory to the practice or application of fish fogging. The achievement of community service activities is the transfer of knowledge about making fish fogging machines and the practice and application of fish fogging directly by the fishermen of Langkak Village. In addition, other results are a manual guide on fish fogging to get the optimal fish fogging results. This activity received a good response from the fishermen of Langkak Village who participated in the activity, because it was considered very useful and became a facility to empower fishermen and residents in general.
\end{abstract}

Keywords: Fish; Fish Fogging Machine; Community Service

\begin{abstract}
Abstrak
Ikan adalah salah satu spesies yang banyak diminati oleh konsumen, termasuk di Aceh. Ikan dapat diperoleh dengan menangkap dari alam yang berlimpah. Masalah dalam pengolahan hasil tangkapan ikan di Aceh, khususnya Desa Langkak, Kecamatan Kuala Pesisir, Kabupaten Nagan Raya adalah metode pemrosesan pasca penangkapan konvensional, yaitu pengeringan menggunakan panas sinar matahari. Dalam kondisi ini, pengeringan ikan memiliki beberapa kelemahan, yang terkait dengan ketergantungan pada panas sinar matahari, kebersihan, kesegaran ikan, dan nilai jual. Untuk alasan ini, perlu adanya cara untuk menerapkan teknologi sederhana yang menggunakan mesin pengasapan ikan. Tujuan dari melaksanakan program pengabdian masyarakat ini adalah untuk memberikan aplikasi praktis dari teknik pengasapan ikan dengan memberikan soft skill kepada anggota kelompok nelayan di Desa Desa Langkak, Kecamatan Kuala Pesisir, Kabupaten Nagan Raya. Hasil kegiatan pengabdian masyarakat telah berjalan dengan baik, dimulai dengan kegiatan sosialisasi atau teori hingga praktik atau penerapan pengasapan ikan. Pencapaian kegiatan pengabdian masyarakat adalah alih pengetahuan tentang pembuatan mesin fumigasi ikan dan praktik serta penerapan fumigasi ikan secara langsung oleh nelayan Desa Langkak. Selain itu, hasil lainnya adalah panduan manual tentang pengasapan ikan untuk mendapatkan hasil pengasapan ikan yang optimal. Kegiatan ini mendapat respons yang baik dari para nelayan Desa Langkak yang ikut dalam kegiatan tersebut, karena dianggap sangat bermanfaat dan menjadi fasilitas untuk memberdayakan nelayan dan warga pada umumnya.
\end{abstract}

Kata Kunci: Ikan; Mesin Pengasapan Ikan; Pengabdian Masyarakat 


\section{PENDAHULUAN}

Produksi ikan hasil tangkapan di Indonesia menunjukkan peningkatan yaitu mencapai sekitar 7 juta ton sampai pada akhir tahun 2015 (Duta, 2015). Aceh merupakan kawasan yang dikelilingi lautan dan kaya akan hayati yang berpotensi untuk dikembangkan. Panjang garis pantai Aceh seluruhnya mencapai $2.310 \mathrm{~km}$ dan memiliki luas perairan laut $295.370 \mathrm{~km} 2$. Provinsi Aceh juga berbatasan langsung dengan dua perairan laut yang sangat penting, yaitu Laut Andaman dan Selat Malaka di bagian utara dan timur serta Laut India di bagian barat. Dengan demikian, tidak heran Aceh kaya akan sumber daya laut baik sumber daya hayati maupun sumber daya non hayati.

Salah satu sumberdaya hayati yang dimiliki Provinsi Aceh adalah sumberdaya perikanan dan kelautan. Selama ini, sektor perikanan dan kelautan merupakan salah satu sektor andalan di Provinsi Aceh dimana lebih dari $55 \%$ penduduk Aceh bergantung kepada sektor ini baik secara langsung maupun tidak langsung (Yusuf, 2003). Namun demikian, potensi kelautan dan perikanan tersebut masih belum bisa dimanfaatkan secara optimal karena berbagai hal. Selain itu, potensi kelautan dan perikanan ini masih belum bisa dimanfaatkan untuk meningkatkan perekonomian masyarakat yang hidup di sekitar sumber daya alam tersebut dimana sudah menjadi fakta umum bahwa sebagian besar nelayan di Aceh masih hidup dibawah garis kemiskinan dan tingkat pendidikan yang rendah.

Kabupaten Nagan Raya memiliki kondisi perikanan cukup menggembirakan, ditandai dengan produksi perikanan dari hasil tangkap makin meningkat dari tahun ke tahun. Salah satu wilayah di Nagan Raya dengan produksi ikan tangkap yang menjanjikan adalah Desa Langkak Kecamatan Kuala Pesisir Kabupaten Nagan Raya, di mana lokasi binaan dapat dilihat pada gambar 1.

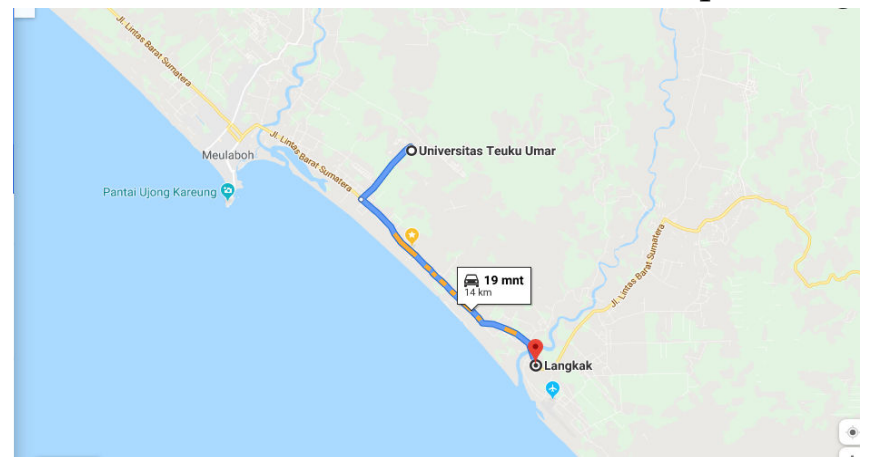

Gambar 1. Lokasi Desa Langkak 
Kecamatan Kuala Pesisir memiliki luas wilayah sekitar 7.634,29 km2 dengan jumlah penduduk 16.299 jiwa. Sedangkan desa langkak memiliki luas daerah 3.552 hektar dan berbatasan langsung dengan laut, denhan jumlah penduduk 1,528 jiwa.

Mata pencaharian utama sebagian besar penduduknya adalah sebagai nelayan maka ketergantungan masyarakatnya terhadap alam dan sumberdayanya sangat tinggi. Terutama potensi dalam sektor perikanan air laut sangat besar. Maka dari itu penduduk Desa Langkak dan sekitarnya sangat bergantung pada laut yang merupakan sumber mata pencaharian nelayan.

Dari pemantauan sekitar Desa Langkak, beberapa jenis ikan tangkapan nelayan setempat merupakan ikan konsumsi seperti Lele, Gabus, Nila, Bandeng, Cakalang, Tongkol Komo, Tongkol Krai, Tuna Sirip Kuning, KambingKambing, Layang, Lisong, Selar, Siro dan Sungkir. Ikan-ikan hasil tangkapan tersebut oleh nelayan tersebut dikeringkan secara alami dengan proses penggaraman dan bantuan sinar matahari dan hasilnya dapat dilihat pada Gambar 2.

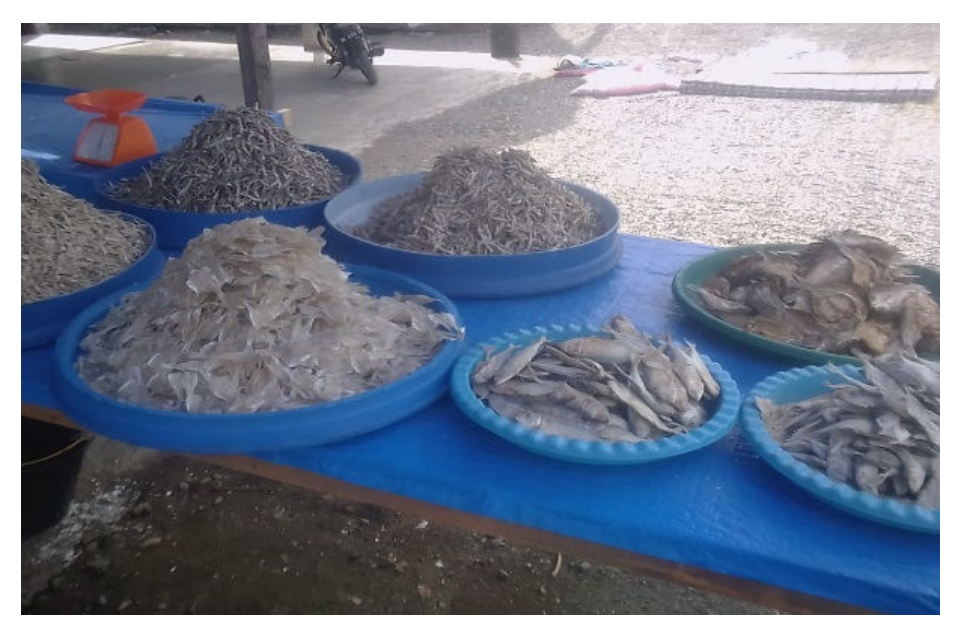

Gambar 2. Ikan Asin di Lokasi

Setelah kering maka ikan tersebut dapat disimpan dan dijual segera. Kondisi tersebut menimbulkan permasalahan yaitu pengeringan ikan sangat tergantung dengan kondisi alam dan kadang cepat busuk karena kurangnya proses pengeringan sehingga menyebabkan nilai jual, cita rasa ikan yang dijual menjadi jatuh.

Mengingat

kondisi

perekonomian yang perlu 
ditingkatkan dan antusiasme masyarakat dalam bidang perikanan, maka perlu adanya kegiatan pemberdayaan masyarakat. Lebih spesifik lagi, nelayan yang tinggal di Desa Langkak Kec. Kuala Pesisir Kabupaten Nagan Raya melakukan kegiatan pengawetan ikan secara sederhana, yaitu setelah ikan ditangkap sebagian akan di jemur. Hal tersebut menimbulkan masalah ketergantungan dengan adanya sinar matahari dan tentu saja tingkat higienitas ikan yang dijemur. Kebanyakan ikan akan dikerubungi lalat. Hal ini tentu saja menurunkan tingkat selera konsumen dan turunnya nilai gizi dan kesehatan pangan. Maka dari itu adanya penerapan teknologi pengasapan ikan untuk meminimalisir turunnya nilai gizi dan higienitas ikan.

Adapun beberapa penelitian terdahulu terkait dengan mesin atau alat pengasapan ikan yaitu, modifikasi dan pengujian alat pengasapan ikan sistem kabinet (Bimantara, 2015), Rancang bangun alat pengasap ikan (Yusuf, 2018), serta desain alat pengasapan ikan menggunakan pendekatan ergonomi, QFD dan pengujian organoleptik (Nurmianto, 2018). Selain itu, penelitian terdahulu mengenai nilai tambah dengan penggunaan pengasapan ikan
(Yusroni, 2009) serta kinerja alat pengasap ikan dan pengaruhnya terhadap kualitas (Susanto, 2014).

Tujuan dari melaksanakan program pengabdian masyarakat ini adalah untuk memberikan aplikasi praktis dari teknik pengasapan ikan dengan memberikan soft skill kepada anggota kelompok nelayan di Desa Desa Langkak, Kecamatan Kuala Pesisir, Kabupaten Nagan Raya.

\section{METODE PELAKSANAAN}

Pelaksanaan program pengabdian masayarakat ini dilaksanakan dengan dua metode, yaitu secara teori dan praktek. Teori akan diberikan sebanyak satu kali, sedangkan metode praktek pembimbingan, pembuatan dan praktek pengasapan ikan akan dilakukan sebanyak tiga kali.

Teori yang diberikan oleh tim pengabdian berupa gambaran umum mengenai perikanan, terutama potensi di Kecamatan Kuala Pesisir Kabupaten Nagan Raya. Selain itu, teori yang diberikan juga mengenai aspek penanganan pasca tangkap ikan terutama tentang pengasapan ikan. Teori akan diberikan dalam bentuk presentasi, diskusi serta tanya jawab dalam satu forum sosialisasi.

Sedangkan metode praktek, tim melakukan pendampingan secara langsung (transfer soft skill) dan 
pendampingan kepada kelompok Nelayan Desa Langkak Kec. Kuala Pesisir Kabupaten Nagan Raya (sekitar 20 orang) mengenai teknik pembuatan mesin pengasapan ikan hingga penggunaannya. Pada akhir praktek, evaluasi program juga akan dilakukan.

\subsection{Teknik Pengasapan Ikan}

$$
\text { Prinsip utama dalam }
$$
pengasapan ikan adalah adanya asap dari pembakaran material kering, dapat berupa kayu, briket, atau bahan yang dapat terbakar (Samuel, 2015). Asap hasil dari pembakaran terdiri atas uap dan partikel padat berukuran mikro. Sementara itu komposisi kimia asap adalah air, aldehid, asam asetat, keton alkohol, asam formiat, fenol dan karbohidrat (Royani, 2014). Asap tersebut dapat mengawetkan ikan dengan cara menghambat dan membunuh bakteri perusak dan pembusuk ikan. Pengasapan dapat menambah awet dengan mencegah terjadinya oksidasi lemak pada ikan serta memberi warna pada daging ikan kuning kecoklatan (Widiyanto, 2015).

$\begin{array}{ccr}\text { Pada } & \text { dasarnya, } & \text { proses } \\ \text { pengasapan } & \text { ikan } & \text { merupakan } \\ \text { gabungan } & \text { dari } & \text { proses }\end{array}$

penggaraman, pengeringan, pemanasan dan pengasapan. Proses penggaraman dilakukan untuk membantu pengawetan ikan. Konsentrasi garam dan lamanya penggaraman disesuaikan dengan selera, jenis, ukuran serta tingkat kesegaran ikan. Garam diberikan agar daging ikan lebih kompak, bakteri pembusuk dapat ditekan pertumbuhannya serta muncul rasa daging lebih enak. Pengeringan dapat juga dilakukan agar proses pengasapan lebih sempurna. Pengeringan tidak harus kering sekali. Pengeringan ini dimaksudkan agar asap dapat masuk ke tekstur daging, pemanasan atau pengasapan, panas yang tinggi akan menghentikan aktivitas enzim perusak daging dan menggumpalkan protein serta membuang air yang masih tertinggal di daging. Lama pengasapan, suhu, dan volume asap mempengaruhi kualitas daging ikan asap (Jeujanan, 2015).

\subsection{Pembuatan Mesin Pengasapan Ikan Mesin pengasap ikan sederhana dirangkai seperti pada Gambar 3.}




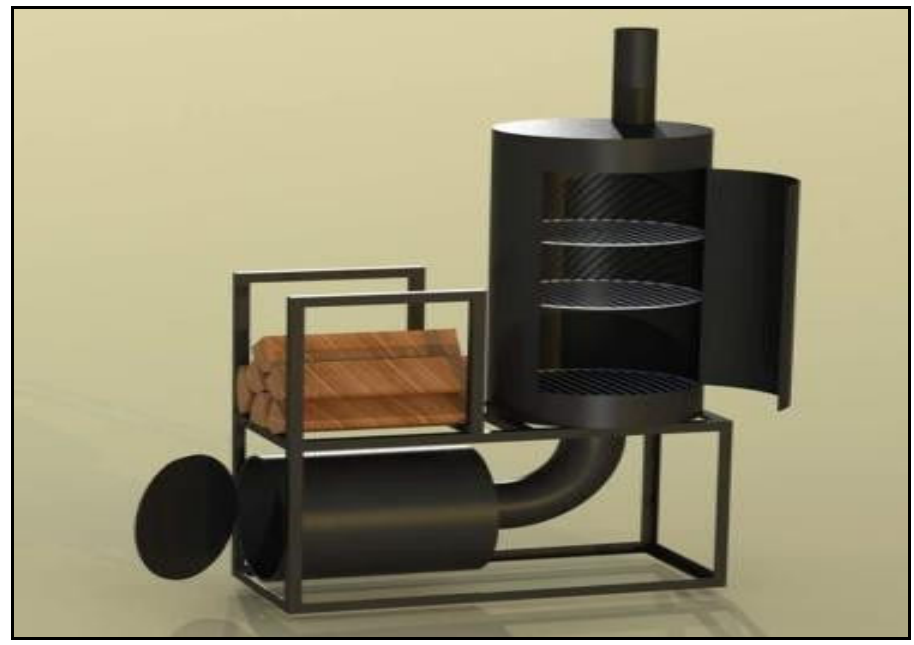

Gambar 3. Rangkaian Mesin Pengasapan Ikan

Seperti pada Gambar 3, mesin pengasapan ikan terbuat dari dua buah drum dan menggunakan bahan/material kayu/batok atau material yang mudah terbakar untuk menimbulkan asap. Mesin ini dapat digunakan untuk pengasapan ikan tawar, laut atau sungai. Bagian cerobong asap dapat diarahkan ke dalam air/sungai agar tidak mencemari udara.

\section{HASIL DAN PEMBAHASAN}

Kegiatan pengabdian kepada masayarakat ini telah dilaksanakan di Desa Langkak Kec. Kuala Pesisir Kabupaten Nagan Raya dan bermitra langsung dengan nelayan di Desa Langkak.

Kegiatan pengabdian kepada masyarakat ini telah diawali dengan pemberian teori dalam bentuk presentasi, diskusi serta tanya jawab dalam satu forum atau sosialisasi yaitu berupa gambaran umum mengenai perikanan, serta aspek penanganan pasca tangkap ikan terutama tentang pengasapan ikan. Lalu dilanjutkan dengan praktek dengan melakukan pendampingan secara langsung (transfer soft skill) dan pendampingan kepada kelompok Nelayan Desa Langkak Kec. Kuala Pesisir Kabupaten Nagan Raya (sekitar 20 orang) mengenai teknik pembuatan mesin pengasapan ikan hingga penggunaannya.

\subsection{Kegiatan Sosialisasi}

Kegiatan sosialisasi pengabdian kepada masyarakat ini dilangsungkan bersama kelompok Nelayan Desa Langkak Kec. Kuala Pesisir Kabupaten Nagan Raya dengan membahas rangkaian kegiatan. Selain melibatkan sekitar 20 orang, sosialisasi juga melibatkan 
aparat kampung dengan harapan mendapatkan solusi dengan permasalahan yang dihadapi oleh nelayan Desa Langkak. Kegiatan sosialisasi dapat dilihat pada gambar 4.

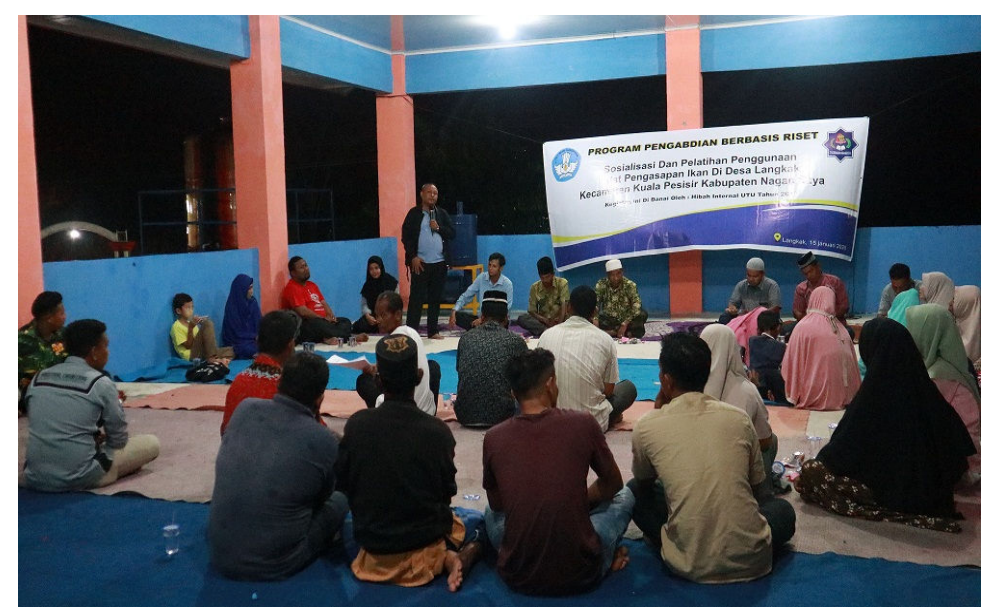

Gambar 4. Kegiatan Sosialisasi

3.2. Kegiatan Merakit Mesin

Mesin pengasapan ikan secara sederhana dibuat dari dua drum minyak yang tidak terpakai serta dibersihkan secara seksama. Kemudian drum dimodifikasi sedemikian rupa hingga dapat menjadi pengasap ikan layaknya oven pada umumnya. Penampang drum dibuat dari rangkaian besi hollow yang kokoh sehingga dapat menahan drum serta bahan baku lainnya saat sedang pengasapan serta juga dapat mempunyai daya tahan yang baik. Material atau bahan baku pengasapan akan menggunakan kayu karena mudah terbakar dan menimbulkan asap yang relatif dan aman untuk kesehatan.

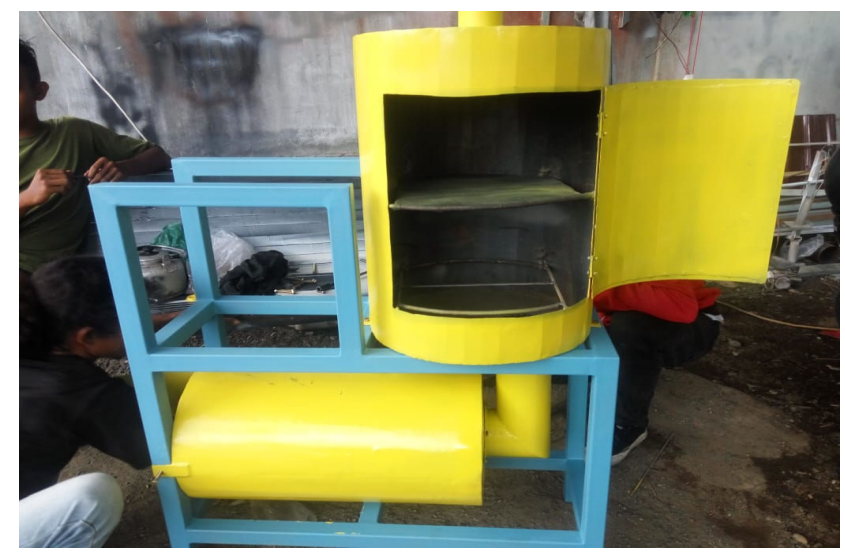

Gambar 5. Mesin Pengasapan Ikan 
Mesin pengasapan ini dapat digunakan secara multifungsi, selain untuk pengasapan ikan air asin dan air tawar, juga dapat digunakan untuk pengasapan bahan makanan lainnya agar awet. Untuk rencana selanjutnya, mesin ini dapat dikembangkan lagi baik itu dalam bentuk desain yang ergonomis maupun dengan tambahan fungsi lainnya. Adapun mesin pengasapan dapat dilihat pada gambar 5 di atas.

\subsection{Kegiatan Praktek dan} Penerapan Pengasapan Ikan

Praktek pengasapan ikan dilakukan langsung oleh nelayan Desa langkah. Adapun ikan yang diasapi adalah ikan segar tanpa bahan tambahan lainnya (tanpa garam). Ikan yang telah bersih dari isi dalamnya kemudian diasapi dan hasilnya pun cukup memuaskan dan sesuai dengan harapan. Adapun percobaan laiinya dengan menggunakan garam juga dirasa berhasil dan sangat memuaskan.

Setelah kegiatan praktek secara langsung selesai, maka selanjutnya dilakukan kegiatan serah terima mesin pengasapan ikan beserta panduan manual kepada nelayan Desa Langkak Kec. Kuala Pesisir Kabupaten Nagan Raya agar dapat diterapkan dan dimanfaatkan seoptimal mungkin dalam rangka meningkatkan nilai jual dan meminimalisir waktu dan biaya yang digunakan.

\section{PENUTUP}

Kegiatan pengabdian kepada masyarakat telah berlangsung dengan baik, yang dimulai kegiatan sosialisasi/teori hingga praktek/penerapan pengasapan ikan. Capaian kegiatan pengabdian kepada masyarakat ini adalah transfer pengetahuan mengenai pembuatan mesin pengasapan ikan serta praktek dan penerapan pengasapan ikan secara langsung oleh nelayan Desa Langkak. Selain itu, output lainnya adalah panduan manual tentang pengasapan ikan agar mendapatkan hasil pengasapan ikan yang optimal. Kegiatan ini mendapatkan respon yang baik dari nelayan Desa Langkak yang mengikuti kegiatan, karena dianggap sangat bermanfaat dan menjadi sarana pemberdayaan nelayan dan warga pada umumnya dalam melakukan pengasapan ikan. Nelayan juga mengharapkan keberlanjutan pemanfaatan kegiatan ini yang ditandai dengan animo yang baik untuk mengasapakan ikan segar hasil tangkapan sehingga meningkatkan nilai ekonomis ikan.

\section{DAFTAR PUSTAKA}

Bimantara, F., Supriadi, A., \& Hanggita, S. 2015. Modifikasi dan Pengujian Alat Pengasapan 
Ikan Sistem Kabinet. Jurnal Fishtech, 4(1), 46-56.

Duta D. K. 2015. Pemerintah Optimis Produksi Ikan Tangkap RI 8 Juta Ton Ekonomi. CNN Indonesia.

Jeujanan, S., Ijong, F. G., Onibala, H., \& Mentang, F. 2015. Organoleptic quality and TPC of smoked skipjack tuna (Katsuwonus pelamis, L) in Jayapura, Papua. AQUATIC SCIENCEE MANAGEMENT, $3(1), 26-31$.

Nurmianto, E., Wessiani, N. A., \& Megawati, R. 2018. Desain alat pengasapan ikan menggunakan pendekatan ergonomi, QFD dan pengujian organoleptik. MATRIK (Jurnal Manajemen dan Teknik Industri Produksi), 10(2), 68-82.

Royani, D. S., Marasabessy, I., Santoso, J., \& Nurimala, M. 2014. Rekayasa Alat Pengasapan Ikan Tipe Kabinet (Model Oven). Jurnal Aplikasi Teknologi Pangan, 4(2).

Samuel, S., Martono, K. T., \& Susanti, M. T. 2015. Pemberdayaan Masyarakat Pesisir Pantai di Tambak Lorok, Semarang, Jawa Tengah. KAPAL: Jurnal Ilmu Pengetahuan dan Teknologi Kelautan, 12(3), 145-150.

Susanto, E. 2014. Mempelajari Kinerja Alat Pengasap Ikan Tipe Cabinet dan Pengaruhnya terhadap Mutu Ikan Asap.
Warta Industri Hasil Pertanian, 31(01), 32-38.

Yusroni, N. 2009. Analisis Profit Margin Untuk Meningkatkan Nilai Tambah Pendapatan Antar Pengrajin Pengasapan Ikan Manyung, Ikan Tongkol dan Ikan Pari Di Bandarharjo Semarang. AKSES: Jurnal Ekonomi dan Bisnis, 4(8).

Yusuf, M., Aprilla, Y., Mardotillah, I., \& Saputra, A. D. 2018. Rancang Bangun Alat Pengasap Ikan. Agroteknika, 1(1), 21-30.

Widiyanto, W. N., Ibrahim, R., \& Anggo, A. D. 2015. The effect of processing temperature of simple steam jacket on the quality of white spotted whipray rays liver oil. Jurnal Pengolahan Hasil Perikanan Indonesia, 18(1). 